\title{
Winter Habitat Use by Moose, Alces alces, in Central Interior British Columbia
}

\author{
Gilbert ProulX ${ }^{1}$ and RHONDA M. KARIZ ${ }^{2}$
}

${ }^{1}$ Alpha Wildlife Research \& Management Ltd., 229 Lilac Terrace, Sherwood Park, Alberta T8H 1W3 Canada

${ }^{2}$ Driftwood Forestry Consulting, 16880 Schefer Drive, Prince George, British Columbia V2K 5L4 Canada

Proulx, Gilbert, and Rhonda M. Kariz. 2005. Winter habitat use by Moose, Alces alces, in central interior British Columbia. Canadian Field-Naturalist 119(2): 186-191.

In central British Columbia, recent epidemics of Mountain Pine Beetle (Dendroctonus ponderosae) have resulted in the use of expansive clearcut areas to remove infested mature and old Lodgepole Pine (Pinus contorta) stands. This study aimed to determine if Moose (Alces alces) use late-successional Lodgepole Pine stands in mid- to late-winter. Moose activity and habitat use was determined during February-March track surveys in 2000 (60 km) and 2001 (55.7 km). In 2000 (69 tracks) and 2001 (313 tracks), Moose track distribution differed significantly $(P<0.05)$ from random. They were significantly more abundant than predicted in young stands (dominated by Picea spp.), or early seral stages; they were less abundant than predicted in mature and old Lodgepole Pine stands. It is unlikely that harvesting late-successional Lodgepole Pine stands would affect Moose winter habitat supply.

Key Words: Alces alces, Moose, snowtracking, Lodgepole Pine, Pinus contorta, British Columbia.

Most work suggests that a proper interspersion of food and shelter in winter can be an important and possibly limiting feature of Moose (Alces alces) habitat (Welsh et al. 1980; Proulx and Joyal 1981; Peek et al. 1987). Timber harvesting may have a positive effect on Moose by creating early seral stages rich in browse. On the other hand, it may be detrimental to Moose, particularly in winter, if a mosaic of varied cover types and regeneration sites is not properly maintained (Telfer 1970).

In central British Columbia, recent epidemics of Mountain Pine Beetle (Dendroctonus ponderosae) have resulted in the infestation of at least 4.2 million hectares of mature and old Lodgepole Pine (Pinus contorta) stands (generally $>80$ years), and the use of expansive clearcut silviculture programs to recover the timber (Readshaw 2003*). Moose is a species highly valued by local residents and native groups, and the B.C. Ministries of Forests and Water, Lands, and Air Protection voiced their concerns regarding the removal of Lodgepole Pine cover and the possible reduction in Moose winter habitat.

This study aimed to determine if Moose used late-successional Lodgepole Pine stands in mid- to late-winter, when relatively deep snow and low temperatures force animals to seek canopy cover with welldeveloped understories (Thompson and Stewart 1997). Because late-successional pine stands do not usually offer a multi-storied cover and a well-developed understory, we hypothesized that Moose would make little use of late-successional lodgepole pine.

\section{Study Area}

The study area was located near Burns Lake $\left(54^{\circ} 14^{\prime} \mathrm{N}\right.$, $\left.125^{\circ} 46^{\prime} \mathrm{W}\right)$, in central British Columbia, $350 \mathrm{~km}$ west of Prince George. It encompassed an $80 \mathrm{~km}^{2}$ area that is part of the Sub-Boreal Spruce Biogeoclimatic (SBS) Zone (Meidinger and Pojar 1991). The climate of the SBS zone is continental, and is characterized by seasonal extremes of temperatures, i.e., severe winters and relatively warm, moist, and short summers (Meidinger et al. 1991). The SBS is part of the Canadian Boreal Forest Region (Krajina 1965). Upland coniferous forests dominate the sub-boreal landscape. Hybrid White Spruce (Picea engelmanii $\times$ glauca) and subalpine fir (Abies lasiocarpa) are the dominant climax tree species. Lodgepole Pine is common in mature forests in the drier parts of the zone, and both Lodgepole Pine and Trembling Aspen (Populus tremuloides) pioneer the extensive early-seral stands (Meidinger et al. 1991). Wetlands are common and dot the landscape in poorly drained, postglacial depressions or river ox-bows. Wetland community types include sedge (Carex spp.) marshes, and fens with birch (Betula spp.), willows (Salix spp.), Black Spruce (Picea mariana), and hybrid spruce (P. glauca $\times$ P. mariana) (Meidinger et al. 1991).

Winter was generally harsher in 2000 than in 2001. In February, in situ data collections indicated that temperatures ranged from -28 to $2^{\circ} \mathrm{C}$ in 2000 . They ranged from -24 to $9^{\circ} \mathrm{C}$ in 2001 , but most days were between -4 and $0^{\circ} \mathrm{C}$. During both years, surface conditions consisted of loose granular snow without crust, and hooves of Moose penetrated deeply into the snow. Mean snow depths of most habitats were significantly greater in 2000 than in 2001; on average, mean snow accumulation was $11.7 \mathrm{~cm}$ deeper in 2000 than in 2001 (Proulx and Kariz 2001*). In February 2000, mean snow depths approximated $43 \mathrm{~cm}$ in coniferous forests and $62 \mathrm{~cm}$ in openings/immature stands. In 2001, they averaged 33 and $52 \mathrm{~cm}$ in the same respective habitats. 


\section{Methods}

Track surveys

Moose activity and habitat use was determined during two consecutive surveys each year: from 4-11 February and 24 February-1 March, 2000, and 30 January-5 February and 1-6 March, 2001. Each survey consisted of seven line transects crossing the study area. The same transects were used during both years, with some deviations due to open water in 2001. Transect lengths also varied within and between years due to accessibility (e.g., extensive, recent blowdowns interfered with researchers' movements) and environmental conditions (e.g., sudden change of weather with heavy snowfall); they ranged from 3.6 to $5.4 \mathrm{~km}$, and were oriented to avoid paralleling roads (Cairns and Telfer 1980). They were plotted on forestry maps, and starting points were tied by compass bearings and distance to distinctive topographic features. Transects were snowshoed using a compass and 1:20 000 forestry maps; linear distance along a survey transect was determined with a hip chain and recorded each time there was a change of habitat type. Because the study focused on assessing the use of pine stands by Moose, habitat classification was kept simple, and limited to four types based on the British Columbia Resources Inventory Committee's (1998*) classes (Table 1).

Because Moose may take advantage of packed snowshoe trails in their daily movements (E. Telfer, Canadian Wildlife Service, personal communication), different transects were used from one survey period to the other during a same year. Each year, transects of the second survey period were placed in between those of the first survey. In winter, Moose usually move $<1 \mathrm{~km}$ during their daily wanderings (Phillips et al. 1973; Hundertmark 1997) and, in order to avoid problems associated with pseudoreplication (Hurlbert 1984), transects of a same survey period were located at least $1 \mathrm{~km}$ apart. Therefore, tracks encountered in different transects during a survey period were likely from different animals. Along transects, because it was not possible to consistently determine if crossings were made by the same animal, all crossings were tallied (Raphael and Henry 1990*). Only fresh tracks were recorded.

\section{Data analyses}

All track transects were surveyed within one month, under similar weather conditions. Transects of the first and second surveys within a same year were pooled together for data analyses. Student $t$-test was used to compare mean numbers of tracks/transect between years. Pair-sampled $t$-testing was used to compare differences in the number of tracks recorded along a same transect from one year to the other (Zar 1999). Proportions of habitat classes traversed by survey transects were used to determine the expected frequency of track intersects per habitat class if tracks were distributed randomly with respect to habitat classes (Parker et al. 1981). Chi-square statistics with Yates correction (Zar 1999) were used to compare observed to expected fre- quencies of track intersects per habitat class. When chi-square analyses suggested an overall significant difference between the distribution of observed and expected frequencies, comparisons of observed to expected frequencies for each habitat class were conducted using a G-test for correlated proportions (Sokal and Rohlf 1981). Probability values $\leq 0.05$ were considered statistically significant.

\section{Results}

\section{Transects'vegetation composition}

A total of 60 and $55.7 \mathrm{~km}$ were snowshoed in 2000 and 2001, respectively. Vegetation composition along transects was similar during both years $\left(\chi^{2}: 0.85\right.$, df: 5, $P>0.05$ ) (Figure 1).

\section{Frequency of Moose tracks/transect by year}

On average, the number of Moose tracks/transect was significantly lower $(t=4.79, P<0.05)$ in 2000 ( $n$ : 14 transects, $\bar{x}=4.9$ tracks, standard deviation $=$ 4.2 tracks) than in 2001 ( $n: 14, \bar{x}=22.3 \pm 12.9$ tracks). The number of tracks/transect ranged from 0 to 17 in 2000, and from 4 to 46 in 2001. Differences observed in the number of tracks recorded along a same transect from one year to the other were highly significant $(t=$ 5.16, $P<0.001)$.

\section{Frequency of Moose tracks per habitat type}

In 2000, 69 fresh Moose tracks were encountered. The observed frequency of tracks per habitat class was significantly different $\left(\chi^{2}=23.62\right.$, df: $5, P=0.001$; Figure 2) from a random distribution of tracks among habitat classes. Tracks were significantly more abundant than predicted in young stands $(\mathrm{G}=4.19$, df: 1 , $P<0.05)$ (Figure 2). They were less abundant than predicted in late-successional pine stands $(\mathrm{G}=8.21$, df: $1, P<0.01$ ) (Figure 2).

In 2001, 313 fresh Moose tracks were encountered. The observed frequency of tracks per habitat class was significantly different $\left(\chi^{2}=81.06\right.$, df: $5, P<0.001$; Figure 3 ) from a random distribution of tracks among habitat classes. Tracks were significantly more abundant than predicted in openings and immature 1 stands ( $\mathrm{G}=7.83$, df: $1, P<0.01)$, and in immature 2 , scrub and pole stands $(\mathrm{G}=3.85$, df: $1, P<0.05)$. They were less abundant than predicted in late-successional pine stands (G = 35.12, df: $1, P<0.001)$ (Figure 3 ).

\section{Discussion}

During the cold winter of 2000 and the warmer winter of 2001, this study validated our expectation that Moose make little use of late-successional Lodgepole Pine in mid- to late-winter. The low use of late-successional pine stands may be explained by a generally poor understory with few deciduous shrubs for browse, and the lack of a multi-storied vertical cover (Raphael et al. $1992 *)$.

During the two winters, Moose used a mosaic of habitat patches that offered deciduous shrubs for food and coniferous canopy for shelter. However, habitat 
TABLE 1. Habitat types used in the study of Moose habitat use in February-March 2000 and 2001 in central British Columbia (after British Columbia Resources Inventory Committee's (1998) classes).

\begin{tabular}{|c|c|}
\hline Forest type & Characteristics \\
\hline Deciduous & Crown closure $\geq 10 \%$, deciduous species $>75 \%$ \\
\hline $\begin{array}{l}\text { Coniferous } \\
\quad-\text { Pure } \\
- \text { Mixed }\end{array}$ & $\begin{array}{l}\text { Crown closure } \geq 10 \% \text {, coniferous species }>75 \% \\
\text { When } \geq 80 \% \text { of the coniferous cover is provided by one species. } \\
\text { When the coniferous cover is provided by more than one species, neither } \\
\text { species } \geq 80 \%\end{array}$ \\
\hline Coniferous-deciduous & Crown closure $\geq 10 \%$, neither type $>75 \%$ \\
\hline Habitat type & Description \\
\hline Openings and immature 1 stands & $\begin{array}{l}0-10 \text { years old. Open areas with sparse shrubs, and replanted clearcuts with } \\
\text { trees }<2 \mathrm{~m} \text { high. }\end{array}$ \\
\hline Immature 2, pole, and scrub & $\begin{array}{l}\text { 11-40 years old. Immature } 2 \text { stands represent new forests following a natural } \\
\text { or anthropogenic disturbance, with trees } \geq 2 \mathrm{~m} \text { high. Pole stands are thick } \\
\text { stands of trees ( } 7.5 \text { to } 12.4 \mathrm{~cm} \text { diameter at breast height), usually with little } \\
\text { understory. Trees compete with one another and other plants for light, water, } \\
\text { nutrients, and space to the point where most other vegetation and many trees } \\
\text { become suppressed and die. Scrubs are typical lowlands and bogs with short } \\
\text { Black Spruce and/or willow or alder thickets. }\end{array}$ \\
\hline Young & $\begin{array}{l}40-80 \text { year-old forests consisting mainly of spruce-dominated stands. } \\
\text { Achievement of dominance by some trees and death of other trees leads to } \\
\text { reduced competition that allows understory plants to become established. The } \\
\text { forest canopy has begun differentiation into distinct layers. Vigorous growth } \\
\text { and a more open and multi-storied stand than in the pole stage. }\end{array}$ \\
\hline Late successional & $\begin{array}{l}\geq 81 \text { years old forests consisting mostly of mature stands with even canopy of } \\
\text { trees, with or without coarse woody debris down and leaning logs. A few old } \\
\text { stands with tall and large canopy trees, canopy gaps, large snags, large downed } \\
\text { woody debris, and developed understories. A second cycle of shade tolerant } \\
\text { trees may have become established. Multi-layered canopy and developed } \\
\text { understories usually missing in late-successional pine stands. }\end{array}$ \\
\hline
\end{tabular}

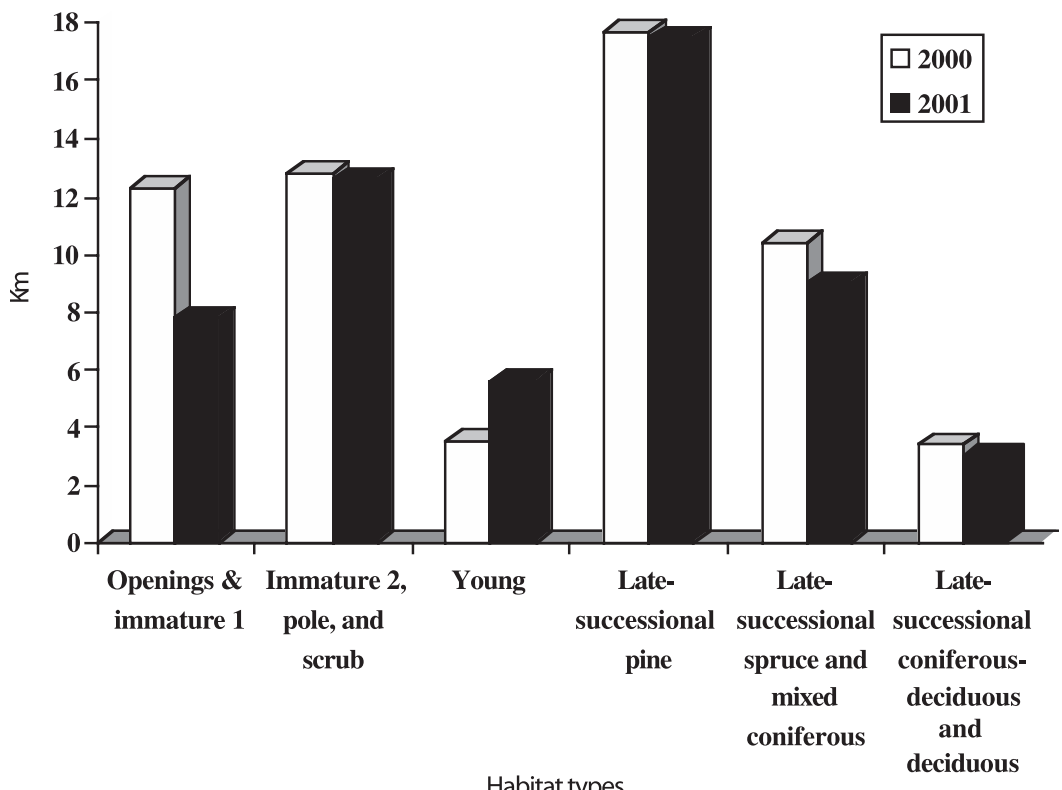

FIGURE 1. Distance traveled through each habitat type during Moose track surveys in central British Columbia, in February-March 2000 and 2001. 


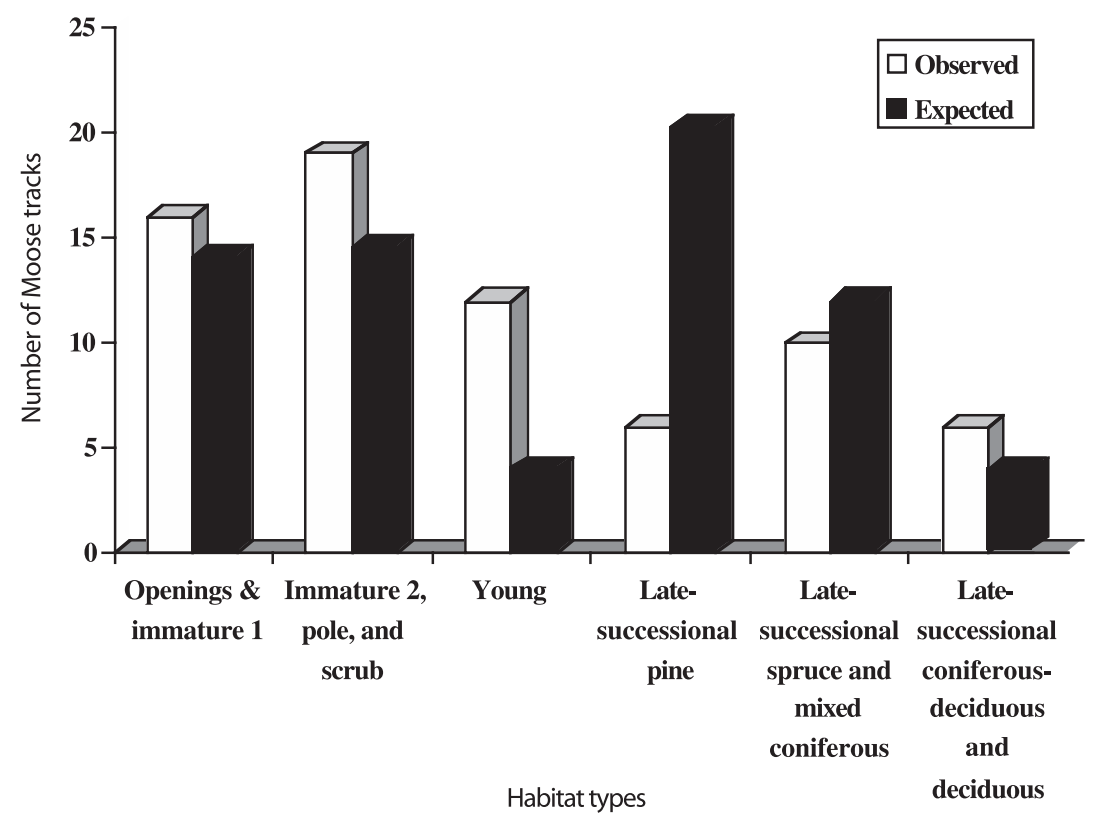

FIGURE 2. Observed and expected number of Moose tracks per habitat type in central British Columbia, February-March 2000.

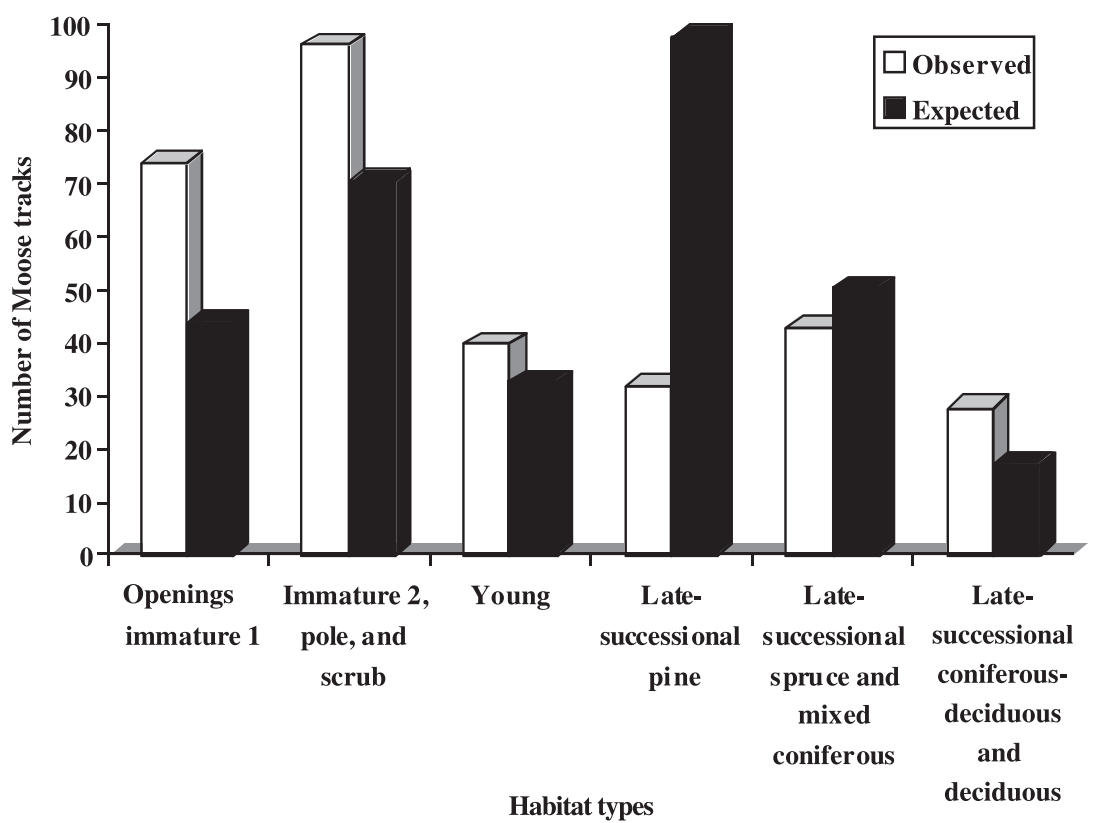

FIGURE 3. Observed and expected number of Moose tracks per habitat type in central British Columbia, February-March 2001.

mosaics used by Moose varied in composition between years. Moose were less active in 2000 than in 2001 , as suggested by the markedly lower number of recorded tracks. In February-March 2000, Moose tracks were found in a variety of young and mature stands. Moose apparently sought habitats that offered both cover and food. The use of such habitats may occur with relatively shallow snow (Sandegren et al. 1985; Hundertmark 1997) and low temperatures (Schwartz and Renecker 1997), and has been reported 
in many regions (Stevens 1970; Eastman 1974; Rolley and Keith 1980). In February-March 2001, Moose tracks were more abundant than predicted on the basis of a random distribution in openings with vegetation, immature stands and scrub. Moose can experience heat stress in winter when temperatures rise above $-5^{\circ} \mathrm{C}$ (Schwartz and Renecker 1997); they may have used these habitats because they are rich in browse, but are also more open, windier, and cooler than forests (Renecker and Schwartz 1997).

It is unlikely that harvesting late-successional lodgepole pine stands to address Mountain Pine Beetle infestations would impact on Moose winter habitat supply. However, Moose may use pine stands to travel between wetlands and young forests, and cross clearcuts (Proulx, personal observation). Then, if pine stands are retained as connectivity corridors across the landscape, non-clearcut silviculture treatments may be warranted to sanitize beetle-infested stands and provide traveling Moose with protective cover.

\section{Acknowledgments}

We thank the British Columbia Ministries of Environment, and Water, Land and Air Protection for inquiring about Moose winter habitat, and Canadian Forest Products Ltd. (Canfor), Houston Operations, for funding the study. We thank Carl Vandermark, Canfor, for his interest in this study, and Joel Nicholson for technical help. We thank two anonymous referees for their valuable comments.

\section{Documents Cited (marked * in text)}

British Columbia Resources Inventory Committee. 1998. Standard for terrestrial ecosystem mapping in British Columbia. Resource Inventory Committee, Victoria.

Proulx, G., and R. Kariz. 2001. Moose winter habitat in Canfor's Operating Area in Lakes Forest District, British Columbia, 1999-2001. Alpha Wildlife Research \& Management Ltd. report prepared for Canadian Forest Products Ltd., Houston, British Columbia.

Raphael M. G., and S. E. Henry. 1990. Preliminary suggestions for monitoring Marten in the Rocky Mountains region. United States Department of Agriculture, Forest Service. Pacific Northwest Forest Science Laboratory, Olympia, Washignton. 6 pages.

Raphael, M., S. L. Marquardt, and R. H. Barrett. 1992. Evaluating stand conditions to support integrated sylvicultural pescriptions for timber and wildlife: snags and old growth. Pages 1-20 in Proceedings habitat futures workshop, Edited by J. B. Nyberg and W. B. Kessler, Pacific Experimental Forest, British Columbia Mininstry of Forests, Victoria.

Readshaw, K. 2003. Timber supply analysis, Mountain Pine Beetle infestation. British Columbia Ministry of Forests, Victoria. Mimeograph.

\section{Literature Cited}

Cairns, A. L., and E. S. Telfer. 1980. Habitat use by 4 sympatric ungulates in boreal mixedwood forest. Journal of Wildlife Management 44: 849-857.
Eastman, D. S. 1974. Habitat use by Moose of burns, cutovers and forests in northcentral British Columbia. Proceedings. North American Moose Conference Workshop 10: 238-256.

Hundertmark, K. J. 1997. Home range, dispersal and migration. Pages 303-335 in Ecology and management of the North American Moose. Edited by W. Franzmann and C. C. Schwartz. Wildlife Management Institute Book, Smithsonian Institute Press, Washington, D.C.

Hurlbert, S. H. 1984. Pseudoreplication and the design of ecological field experiments. Ecological Monographs 59: 67-77.

Krajina, V. J. 1965. Biogeoclimatic zones and biogeocoenoses of British Columbia. Ecology Western North America 1: 1-17.

Meidinger, D., and J. Pojar. Editors. 1991. Ecosystems of British Columbia. British Columbia Ministry Forests, Special Report. Series. 6. 330 pages.

Meidinger, D., J. Pojar, and W. L., Harper. 1991. Chapter 14: Sub-boreal spruce zone. Pages 209-221 in Ecosystems of British Columbia. Edited by D. Meidinger and J. Pojar. British Columbia Ministry Forests, Special Report Series 6.

Parker, G. R., J. W. Maxwell, L. D. Morton, and G. E. J. Smith. 1981. The ecology of the Lynx (Lynx canadensis) on Cape Breton Island, Nova Scotia. Pages 221-248 in Worldwide furbearer conference proceedings. Edited by J. A. Chapman and D. Pursley, Frostburg, Maryland:

Peek J. M., D. J. Pierce, D. C. Graham, and D. L. Davis. 1987. Moose habitat use and implications for forest management in northcentral Idaho. Swedish Wildlife Research. (Supplement) 1: 195-199.

Phillips R. L., W. E. Berg, and D. B. Siniff. 1973. Moose movement patterns and range use in northwestern Minnesota. Journal of Wildlife Management 37: 266-278.

Proulx G., and R. Joyal. 1981. Forestry maps as an information source for description of Moose winter yards. Canadian Journal of Zoology 59: 75-80.

Renecker, L. A., and C. C. Schwartz. 1997. Food habits and feeding behavior. Pages 403-439 in Ecology and management of the North American Moose. Edited by A. W. Franzmann and C. C. Schwartz, Wildlife Management Institute. Book, Smithsonian Institute Press, Washington, D.C.

Rolley, R. E., and L. B. Keith. 1980. Moose population dynamics and winter habitat use at Rochester, Alberta, 1965-1969. Canadian Field-Naturalist 94: 9-18.

Sandergren, F., R. Bergstron, and P. Y. Sweanor. 1985. Seasonal Moose migrations related to snow in Sweden. Alces 21: 321-338.

Schwartz, C. C., and L. A. Renecker. 1997. Nutrition and energetics. Pages 441-478 in Ecology and management of the North American Moose. Edited by A. W. Franzmann and C. C. Schwartz, Wildlife Management Institute. Book, Smithsonian Institute Press, Washington, D.C.

Sokal R. R., and F. J., Rohlf. 1981. Biometry. $2^{\text {nd }}$ edition. W. H. Freeman and Co., San Francisco, California.

Stevens, D. R. 1970. Winter ecology of Moose in the Gallatin Mountains, Montana. Journal of Wildlife Management 34: 37-46.

Telfer, E. S. 1970. Relationships between logging and big game in eastern Canada. Pulp \& Paper Magazine Canada, October Issue: 69-73. 
Thompson I. D., and R. W. Stewart. 1997. Management of Moose habitat. Pages 377-401 in Ecology and management of the North American Moose. Edited by A. W. Franzmann and C. C. Schwartz, Wildlife Management Institute Book, Smithsonian Institute Press, Washington, D.C.

Welsh, D. A., K. P Morrison, K. Oswald, and E. R. Thomas. 1980. Winter habitat utilization by Moose in relation to forest harvesting. Proceedings North American Moose Conference Workshop 16: 398-428.

Zar, J. H. 1999. Biostatistical analysis, $4^{\text {th }}$ edition, Prentice Hall, New Jersey, USA.

Received 24 November 2003

Accepted 14 March 2005 